\title{
Waar lê die "sondige verskeurdheid" rondom die gebeure van 1859 met die afskeiding van die Gereformeerde Kerk?
}

\section{JOH DREYER}

Dit is 'n verskynsel wat meermale voorkom dat, wanneer 'n kerk te groot word en daardeur die intimiteit van die kleiner kring op die agtergrond raak, meningsverskille onder die lede al hoe meer na vore kom. Hierdie meningsverskille skep geleidelike geskille en laat ook rigtings ontstaan oor allerhande praktiese, liturgiese en teologiese probleme - in Nederland teenswoordig bestempel as modaliteite. Die verskille word geleidelik al skerper gestel en al fyner uitgewerk waardeur daar 'n kloof ontstaan tussen die verskillende rigtings of modaliteite. Die algemene benamings vir hierdie verskillende groepe in dieselfde kerkverband is gewoonlik konserwatief en liberaal, óf regs en links, óf ortodoks en modern. Teenswoordig kom die benamings: "Christelik en Marxisties, godsdienstig en ateïsties steeds meer na vore."

In Nederland was gedurende die vorige eeu in die Hervormde Kerk ' $n$ hele paar rigtings soos die Konfessionele vereniging, die Gereformeerde Bond, die Etiese rigting, die Modern rigting en so meer. Na die jongste wêreldoorlog het die ou Etiese rigting opgehou om te bestaan en val die Etiese nou onder die sogenaamde Midde-ortodoksie à la Berkhof. ${ }^{1}$

Nou is dit opvallend dat die groot kerke gewoonlik verskillende rigtings huisves en wanneer die verskille verder uitgewerk en verskerp word, word die bodem gevorm waaruit met verloop van tyd afskeidings en skeurings ontstaan. As voorbeelde daarvan noem ons die Nederlandse Hervormde Kerk waaruit reeds twee afskeidings ontstaan het, en die Gereformeerde Kerke wat ook reeds 'n paar afskeidings moes betreur. Die eerste onder die Gereformeerdes was in 1926 onder leiding van dr Geelkerken wat geskors is omdat hy vanaf die Amsterdamse kansel gesê het, dat die slang in die paradys nie met hoorbare menslike stem gespreek het nie. Die tweede afskeiding was in 1945 onder leiding van prof Schilder. Verder noem ons die afskeidings in die Presbiteriaanse kerk in die VSA waardeur nou ongeveer 'n half dosyn Presbiteriaanse kerke aldaar bestaan. Ons noem as voorbeeld daarvan "the Presbyterian Church in the USA; the United Presbyterian Church, the Orthodox Presbyterian Church, the Bible Presbyterian Church, the Reformed Presbyterian Church," om maar net 'n paar te noem. 
Afskeidings het ook in die kleiner kerke voorgekom en soms geskied as gevolg van swaar en diepgaande teologiese verskille, maar ook om ander redes. So byvoorbeeld was die groot rede dat die Christian Reformed Church in die VSA afgeskeur het van die Reformed Church of America eintlik die verdraagsaamheid van laasgenoemde ten opsigte van die Vrymesselary.

Saam met die hoofoorsaak van afskeidings is daar gewoonlik een of meer bykomstige sake wat ook ' $n$ rol help speel, maar die hoofoorsaak wat eintlik in elke geval van afskeiding die deurslag bepaal, moet in die beantwoording van ons vraag, naamlik waar die sondige verskeurdheid rondom die gebeure van 1859 met die afskeiding van die Gereformeerde Kerk lê, onder die loep geneem word.

Die gebeure rondom 1859 is die vrug van die bepaalde godsdienstige gesindheid, die kulturele beskouings en die geringe mate van ontwikkeling van die grensboere aan die noord-oostelike grensdistrikte van die destydse Kaap Kolonie, asook van dié onder hulle wat met die Groot Trek noordwaarts na die Vrystaat en die Transvaal getrek het. Hierdie mense was stoere mense, gevorm onder Bybelse invloede en deur die harde en afgesonderde lewe van die grensboere van dié tyd. Skole was daar nog nie. Die kinders moes aan die knieë van die moeders leer. Die eintlike handboek was die Bybel. Die onderrig kon nie verder as die bekende "Trap der Jeugd" boekie gaan nie.

Die afgesonderde lewe met alleen die ossewa en die perd as vervoermiddels het meegebring dat daar so goed as geen kontakte met ander mense en ander denkbeelde as dié binne die eie kring bestaan het nie. Die vanselfsprekende gevolg hiervan was gebrek aan nuwe insigte en idees en dit het meegebring dat dié mense uiters konserwatief in baie opsigte was: op kerklik-godsdienstige gebied, asook in hulle kleredrag en allerhande volksmaniere. Vandaar dat hulle deur die meer verligte deel van die bevolking, wat met vreemde mense en hulle idees kennis gemaak het, bestempel is as doppers. Hulle beskouings sou met een woord as Puriteins bestempel kan word.

Hierby moet nie uit die oog verloor word nie, dat hulle van die kerklike liggame van dié tyd, soos byvoorbeeld deur die Ring van Graaff-Reinet en met name deur die Skotse predikante, wat in die Afrikaanse gemeentes gedien het, uiters onsimpatiek behandel is. Hulle het die "vreemde" dominees nie altyd verstaan nie en die leraars het die grensboere ook nie verstaan nie.

Hier lê ook een van die wortels van die Afskeiding. En toe die gewese grensboere nog verder noordwaarts weggetrek het van die beskawing en nog meer afgesonder gaan lewe het, het die Puriteinse konserwatisme blykbaar nog dieper wortels in hulle godsdienstige en ander opvattings geslaan. 
Toe dan die evangeliese gesange in die Kaapse kerk in die begin van die negentiende eeu ingevoer is en deurgedring het tot in die twee noordelike provinsies is hulle aangevoel as nuwighede, as ongevraagde indringers, en was daar reeds voor die koms van ds Postma verset daarteen. Hierdie teenstand wat Transvaal betref, het veral gekom uit die Rustenburgse wêreld en is gedra en gelei deur'n paar uiters konserwatiewe families. Onder hulle was daar sterk leidende figure soos die Krugers, die Snymans, die Venters ensovoorts. Voor die koms van ds Postma was daar al besware geopper teen die gebruik van gesange in die eredienste en voorstelle by die Algemene Kerkvergaderinge van die Hervormde Kerk ingedien om die gesange uit die kerk te weer.

Reeds met die Algemene Kerkvergaderings van 1853 op Rustenburg het diaken $S$ Kruger voorgestel om die gesange uit die kerkdiens te verwyder "indien zulks met rede en liefde kan geschieden." Hierdie voorstel is gewysig aangeneem "dat dit den leeraar vry zal staan om Psalmen en Gesangen te laten zingen naar goedvinding terwyl het aan de Gemeente volkomen vry zal staan al of niet mede te zingen." Met die vergadering van 1855 het daar weer ' $n$ voorstel met besware teen die gesange ingekom. Hierdie keer van $\mathrm{Ph}$ Snyman. Hier loer'n moontlike afskeiding al om die hoek, want hy praat van "zich losscheuren van de hier bestaand Kerk en een eigen Kerk op te richten, waarin hy wenscht dat de leraar van der Hoff de dienst waarnam, doch zonder 'n zingen van Gezangen." ${ }^{2}$

$\mathrm{Na}$ hierdie oorsig oor die agtergrond waaruit die beswaar teen die gesange ontstaan het, moet nou eers nagegaan word hoe die twee leidende kerkfigure, die twee predikante, Dirk v d Hoff en Dirk Postma in hierdie aangeleentheid opgetree het. Het hulle die vrug ryp gedruk of is hulle deur die kerklike leiers in die Transvaal van dié tyd in die rigting wat elkeen van hulle ingeslaan het, gedwing? Volgens S P Engelbrecht en Spoelstra het dit met die gesange gegaan net soos met die probleem oor die verbreking van die band met die Kaapse kerk, dit wil sê dat nie ds v d Hoff die Transvaalse kerkleiers gedwing het om die band met die Kaapse kerk te verbreek nie, soos Scholtz beweer, ${ }^{3}$ maar die teenoorgestelde dat die ou stoere Voortrekkerkerkleiers ds $\mathrm{v} d$ Hoff oorreed het om die band te los.

Ds v d Hoff het 'n gematigde standpunt van die begin af ingeneem ten opsigte van die gebruik van gesange in die eredienste naamlik dat dit in die vryheid van die leraar om gesange op te gee, en aan die vryheid van die lidmate om hulle te sing of nie te sing nie, oorgelaat moet word.

Die leidende figuur onder die ouderlinge van dié tyd ouderling $F$ $\mathrm{G}$ Wolmarans, tree sterker as ds $\mathrm{v} d$ Hoff op in verband met die behou van die gesange in die eredienste. Moontlik is onder sy leiding die voorstel van ds $\mathbf{v} d$ Hoff om die opgee van gesange in die eredienste aan die diskresie van die leraar oor te laat in die Algemene 
Kerkvergadering afgestem en is die voorstel aanvaar naamlik dat van die gesange wel gebruik gemaak moet word.

Hierdie besluit was toe die aanleiding vir die beswaarde broeders om die band met die Hervormde Kerk te verbreek en af te skei, wat toe 'n voldonge feit geword het op Rustenburg op 10 Februarie 1859. Ds v d Hoff was die mening toegedaan dat die afskeiding uit die gesangekwessie ontstaan het.

Wat ds Postma betref, kan ook gesê word dat hy nie die leiding teen die gebruik van gesange in die eredienste in sy hande gehad het nie. 'n Skerp teenstander van die gesange was hy nie. Hy het met verskillende eredienste wat hy gelei het in die eerste tyd na sy aankoms in Suid-Afrika gesange laat sing. Met sy aankoms op Potchefstroom het hy genoeë daarmee geneem om die predikante vry te laat om gesange te laat sing en die gemeentelede om saam te sing of nie.

Aan prof Hofmeyer het hy as sy mening uitgespreek dat die gebruik van gesange nimmer as voldoende rede vir afskeiding ${ }^{4}$ aangevoer kan word nie en dat die gesange, mits hulle regsinnig was, nie 'n onoorkomelike beswaar is nie. ${ }^{5}$ Postma het egter net gekom op die tydstip dat die beswaarmakers teen gesange ryp was vir afskeiding. Tereg sê G D Scholtz dat die koms van Postma die gesangeprobleem tot ' $n$ punt gevoer het. ${ }^{6}$ Vir die Rustenburgers, wat nie van die gesange wou weet nie, was die koms van Postma 'n uitkoms. Nou het hulle'n predikant gekry wat liewer nie gesange wil laat sing nie, en die moontlikheid vir afskeiding was nou gunstig. Postma was vir hulle dié man en die afskeiding word op 10 Februarie 1859 'n voldonge feit.

Dat die gesange die eintlike rede was vir die afskeiding blyk uit die feit dat, daar geen besware van die beswaarmakers teen die prediking van ds van der Hoff was nie. Hulle wou hom as predikant ${ }^{7}$ of konsulent behou, maar sonder gesange. Later is wel ander verskilpunte na vore gebring soos oor diens, leer en tug, maar dit eers nadat die afskeiding reeds ' $n$ voldonge feit geword het.

Na hierdie historiese oorsig oor die hoofrede vir die afstigting in 1859 kan ons nou ons aandag bepaal by die vraag: "Waar lê die sondige verskeurdheid rondom die gebeure van 1859 met die afskeiding van die Gereformeerde Kerk?" Die vraag kom daarop neer: Was daar genoeg prinsipiële redes gegrond op die Woord van God om kerkskeuring te regverdig?

Met die beantwoording van hierdie vraag is dit van belang om eers op die volgende punte te let:

(i) Ds van der Hoff het sy leedwese uitgespreek oor die besluit van ds Postma om die band te verbreek. Hy en Postma gee aan mekaar die "broederhand der gemeenschap als overeenstemmende in hetzelfde geloof." ${ }^{8}$ Ondanks die gesangegeskil wil hulle broeders bly in die bediening. 
(ii) Die Gereformeerde Kerk verklaar in sy Akte van Afskeiding die Hervormde Kerk as 'n valse kerk, maar terselfdertyd word die wens uitgespreek dat die liefde tussen die twee kerke nie verflou nie. Dit rym nie met mekaar nie.

(iii) Abr Kruger wat self die leier was in die tweede Afskeiding in Nederland naamlik in 1885 ag die gesange kerkregterlik nie gewettig nie en van Arminiaanse oorsprong, sodat verset daarteen gewettig is, maar tog ag hy dié saak te ondergeskik om die kerke daaroor te verdeel. ${ }^{9}$

(iv) Die redes vir afskeiding is nie ooreenkomstig die Reformatoriese kerkbegrip nie. Dit bots met Artikel 28 en 29 van die Nederlandse Geloofsbelydenis wat leer dat niemand hom van die ware kerk mag afskei nie, en wat aantoon wat die kentekens van die ware kerk is, naamlik die suiwere verkondiging van die Woord en die bediening van die sakramente volgens die instelling van Christus. Wat hierdie twee punte betref het daar nie beswaar teen die Hervormde Kerk ingekom nie.

Omdat 'n mens jou van die valse kerk behoort af te skei, maar die Hervormde Kerk geen tekens daarvan getoon het nie, kan ons alleen maar verklaar dat die Afskeiding in 1859 'n sondige verskeurdheid was. Hoogstens sou die Hervormde Kerk van dié tyd deur die ontevredenes as siek of onsuiwer ten opsigte van die gebruik van die gesange verklaar kon word, maar ten enemale nie as vals nie; en genoegsame redes tot kerkskeuring was daar op hierdie genoemde gronde nie.

(v) Die redes vir die afskeiding is in stryd met die standpunt van die Dordtse Sinode van 1618 hieromtrent: "In beginsel het die Gereformeerde Kerk in Artikel 69 van sy Kerkorde die deur vir nie-skriftuurlike berymings "op een kier gezet" deur liedere toe te laat soos die berymde Geloofsbelydenis, die Môre- en Aandsang, asook die Bedesang voor die predikasie."

Ook op die Dordtse Sinode kan dus geen beroep gemaak word teen die sing van gesange nie, omdat dié sinode ook hier 'n opening gelaat het. Barger sê hiervan: "De toelating van Utenhove's Gezang, al is't ook by wyze van exceptie, maakt een bres in dit bolwerk, klein in omvang, maar niet zonder betekenis." ${ }^{\prime 10}$

(vi) In Gereformeerde kerkkringe word meer kere 'n beroep op Calvyn gedoen vir hulle standpunt teen die gesange. Dit gaan egter nie op nie. Hoewel Calvyn voorkeur aan die psalms van Dawid gee, het die oudste Gereformeerde Psalmboek onder Calvyn in Straatsburg in 1539 tog ook 'n paar gesange bevat, 
naamlik die beryming van Simeon se lofsang, die Onse Vader, die Geloofsbelydenis en die Tien Gebooie. ${ }^{11}$

Selfs ds v d Hoff se standpunt dat die al dan nie opgee van 'n gesang in die erediens aan die vryheid van die leraar oorgelaat moet word, kan teruggevoer word tot die Sinode van Dordrecht van 1574 toe bepaal is: "dat de Gezangen, by Datheen opgenomen worden toegelaten, "tot dat in den Synodo Generali anders besloten sal syn" én die gebruik van die gesang: O Godt die onse Vader bist" word in die vryheid van die Dienare gestel. ${ }^{12}$

Nou ten slotte die vraag: "Was daar genoeg Bybelse gronde om die Afskeiding van 1859 te regverdig?"

Met die beantwoording van hierdie vraag moet die aandag daarop gevestig word, dat die gelowige volk van die Here in die tye voor die totstandkoming van die psalms van Dawid tog ook God geloof het met sang en lied. Sê die Woord dan nie: "Toe het Moses en die kinders van Israel hierdie lied tot eer van die Here gesing?" En dit is wat hulle gesê het: "Ek wil sing tot eer van die Here, want Hy is hoog verhewe. Die perd en sy ruiter het $\mathrm{Hy}$ in die see gewerp. Die Here is my krag en my psalm, en Hy het my tot heil geword . . ." Gen 15:1 e v. Het hulle nie by Beër in die grondgebied van Moab die opdrag gekry nie: "Laat die volk bymekaar kom, dat Ek vir hulle water kan gee? Toe het Israel hierdie lied gesing: "Spring op, o put! Besing hom! .. “Num 21:17 e.v. Lees ons dan nie in Deutr 31:22 nie: “Toe het Moses hierdie lied op die dag opgeskrywe en dit aan die kinders van Israel geleer." Vergelyk ook vers 30 . En wat van die lofsang van Debora in Rigt 5? En word deur Paulus die Nuwe Testamentiese gemeente volgens Ef 5:19 en Kol 3:6 dan nie opgeroep om met psalms en lofsange en geestelike liedere te sing tot eer van die Here nie? Ons vind dus niks in die Bybel wat die sing van gesange belet nie.

Samevattend kom ons dan tot die konklusie dat nóg kerkregterlik, nóg Skriftuurlik, die Afskeiding in 1859 geregverdig kan word.

1 Christelyke Encyclopedie, Deel 3, p 222

2 Engelbrecht, S P E, Geskiedenis van die Ned Herv Kerk van Afrika, p 147

3 Scholtz, Geskiedenis van die Ned H of G Kerk van S.A., p 88

4 Engelbrecht, Ibid, p 152, G.C.P.

5 Scholtz, Ibid, p 151; v d Vyver, prof Dirk Postma, p 230

6 Scholtz, Ibid, p 147

7 Scholtz, Ibid, p 151; v d Vyver, Ibid, p 230

8 Engelbrecht, Ibid, p 158

9 Kuyper, Abr, Christelyke Encyclopedie, Deel 3. p 221

10 Barger, $\mathrm{H} \mathrm{H}$, Ons Kerkboek, p 65

11 Barger, Ibid, p 65

12 Ibid, p 67 